DOI 10.18551/rjoas.2021-12.12

\title{
DEVELOPMENT OF GENERATION Z LOYALTY MODEL ON LOCAL BEAUTY PRODUCT
}

\author{
Karisadini, Hartoyo*, Suharjo Budi \\ School of Business, IPB University, Bogor, Indonesia \\ *E-mail: hartoyo@apps.ipb.ac.id
}

\begin{abstract}
Generation $z$ behavior and interest became relevant to business today and in the future as they predicted to be the next consumer powerhouse. In the last few years, the Indonesian beauty industry has been emerging and is expected to continue showing significant growth in the next few years. Generation $z$ entering the market is marked as a phenomenon that businesses should anticipate as this specific generation seems to have low consumer loyalty. This study aims to develop generation z's loyalty model on local beauty products that include factors that influence consumer loyalty and formulate an alternative approach to improve the company's consumer loyalty. The results show that perceived product quality significantly affects perceived value. In addition, perceived product quality and perceived value significantly influence consumer satisfaction. Furthermore, consumer satisfaction has a significant effect on consumer trust. Consumer satisfaction, consumer trust, and consumer ethnocentrism have a considerable impact on the variable of consumer loyalty. Strategies that the company can imply are increasing product research and development to formulate local lipstick products that provide comfort, developing new color choices according to generation z's preference, showing the product quality assurance certificate, creating social media marketing, and expanding the marketing network of local lipstick products.
\end{abstract}

\section{KEY WORDS}

Consumer ethnocentrism, consumer loyalty, consumer satisfaction, consumer trust, generational cohort.

Consumer behaviors continue to develop along with political, cultural, and socioeconomic changes within the society (Delafrooz, Paim, and Khatibi, 2010). Research from Kredivo \& Katadata Insight Center (2020) shows that Generation Z (18-24 years old) is the most significant contributor to the increase of Indonesia's online shopping transactions in $2019(36 \%)$. One of the reasons for gen z's immense contribution is the fact that they currently dominate Indonesia's population, which is 27,94 percent (BPS, 2021). Behavior and interest shown by gen $\mathrm{z}$ are considered relevant for business today and in the future (Jacobsen and Barnes, 2020). Netzer (2019) even stated that gen z is the next consumer powerhouse expected to have up to 40 percent market share.

Of the many product categories offered, research results show that one of the product categories that Generation Z is interested in is beauty products. This is demonstrated by the number of transactions that reach $16 \%$ of total online shopping through e-commerce (Kredivo \& Katadata Insight Center, 2020). In recent years, the beauty industry in Indonesia has shown significant development. The opportunities offered by the Indonesian beauty industry led to unavoidable competition between businesses. In 2019, BPOM approved 73.806 requests for cosmetic notification, where there has been an increasing trend since 2012. This shows that there is a lot of new beauty products being produced and marketed. The rising number of new competitors is undoubtedly a challenge for businesses. Therefore, companies need to improve consumer loyalty to gain and maintain market share amid the fiercely increasing business competition (Puspaningrum, 2018). Low consumer loyalty is one of the toughest challenges businesses must face regarding Generation Z consumers. This generation is considered a critical consumer and always conducts research on products and compares prices between sellers to get the maximum profit (Schlossberg, 2016). This indicates that the entry of Generation $Z$ into the market is a phenomenon that needs to be 
anticipated by business actors because loyalty is one of the crucial aspects of business sustainability (Chaudhuri and Holbrook, 2001).

Previous research shows the use of consumer loyalty models to determine factors that increase consumer loyalty. Therefore, the development of a Generation Z consumer loyalty model is needed to understand how the generation behaves to fulfill their needs for beauty products. In addition, the development of a loyalty model is necessary to find out factors that are proven to increase consumer loyalty, especially in the local beauty industry, which is currently developing. Furthermore, companies can formulate strategies in the form of managerial implications that local beauty companies can apply to increase the loyalty of Generation Z consumers.

This study aims to develop generation z's loyalty model on local beauty products that include factors that influence consumer loyalty. Said factors are consumer satisfaction, consumer trust, and consumer ethnocentrism. Perceived product quality and perceived value are also included as declared variables that are assumed to influence consumer satisfaction, influencing customer loyalty. Furthermore, to formulate an alternative approach to improve the company's consumer loyalty. This study focuses on Indonesian female consumers belonging to Generation Z, born in 1995 to 2010. The respondents are also limited to those who have purchased local beauty products, which fall under the category of lipstick.

\section{METHODS OF RESEARCH}

This research took place in Indonesia. This research activity was carried out from February 2020 to March 2021. Research activities included literature study, online questionnaire distribution, data processing, and hypothesis testing.

The data in this research consist of primary data and secondary data. Primary data was obtained from the results of online questionnaires that respondents have filled out. Secondary data in the study were obtained from various literature sources, namely books, journals, and articles.

This research used a non-probability sampling technique with a voluntary approach. The sample requirements were determined in this study: Indonesian female respondents belonging to Generation $\mathrm{Z}$ with experience in purchasing local lipstick products. To determine the number of samples, the formula used is $(n-1) \times 2$, with $n=$ number of indicators. Therefore, the coefficient of this research model is (27-1) $\times 2=52$, so the number of samples is in the range of $52 \times 5=260$ people to $52 \times 10=520$ people. However, the number of respondents in this study is 290 people.

This study uses an online questionnaire through Google Docs as a data collection tool. The questionnaires were distributed through links through various social media applications and self-administered surveys, where the questionnaires were distributed directly to the appropriate respondents. The questionnaire is divided into screening, profiling, and the main section with questions related to research variables. The questions related to perceived product quality, consumer satisfaction, consumer trust, consumer ethnocentrism, and consumer loyalty is measured by using a 5-point Likert Scale: (1) strongly disagree; (2) disagree; (3) moderately agree; (4) agree (5) strongly agree. However, perceived value is measured by multiple-choice questions describing respondents' perception of the product's value.

In this study, a descriptive analysis was conducted to describe respondents' characteristics and consumer shopping behavior. The descriptive analysis in this study was carried out using SPSS software. The respondent's distribution analysis was carried out using the Top-Two Boxes and Bottom-Two Boxes methods, where the respondents who chose 3 (moderately agree) were categorized as neutral answers. Meanwhile, respondents who chose 1 (strongly disagree) and 2 (disagree) were categorized as disagree and included in the bottom two boxes, and respondents who chose answers 4 (agree) and 5 (strongly agree) were categorized as agree and included in the top two boxes. Furthermore, this study uses the SEM (Structural Equation Model) to analyze the relationship between conceptual 
and structural variables. The formation of the SEM model in this study will be processed using the LISREL software.

In this study, there are three independent variables: perceived quality, perceived value, and consumer ethnocentrism. There are also two intervening variables used in this study, which are consumer satisfaction and consumer trust. In addition, there is one dependent variable, i.e., consumer loyalty. Flow of the framework of this research is shown in Figure 1.

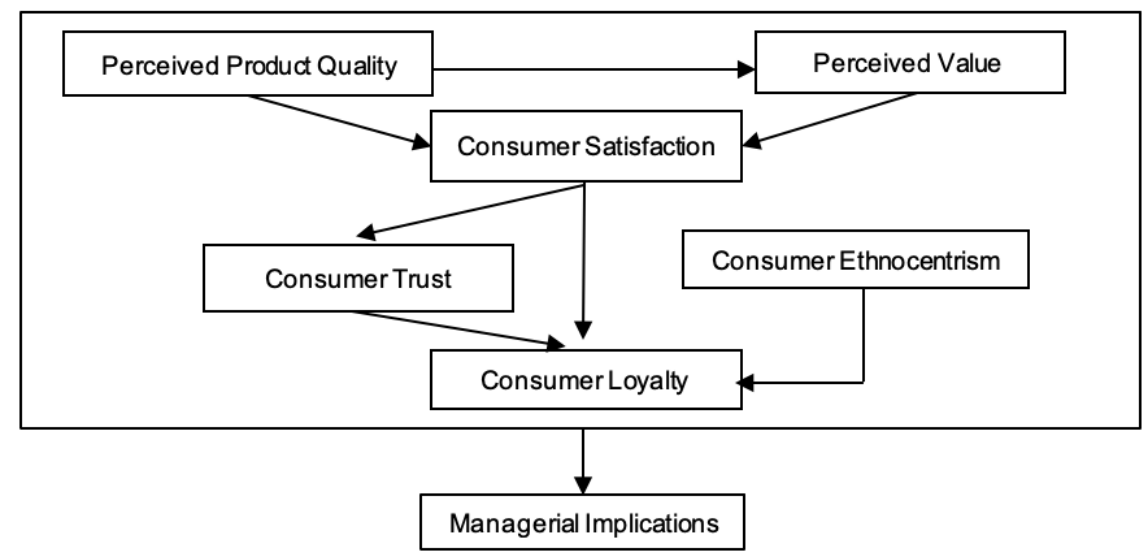

Figure 1 - Research Framework

\section{RESULTS AND DISCUSSION}

Based on the results of descriptive analysis, most of the respondents in this study $(43,7 \%)$ were in the age range of $23-26$ years old. The education level of respondents is grouped into five categories: middle school, High school, Diploma, Bachelor, and Master. The respondents of this study were dominated by undergraduates (46.2\%). Meanwhile, there are seven categories of respondents' occupations such as students, housewives, civil servants, private employees, BUMN employees, entrepreneurs, and unemployed, where 63.4 percent of respondents have jobs as students. The respondents' expenses for personal consumption are mostly Rp 1,000,000 per month (55.5\%). The domiciles of the respondents in this study are spread throughout Indonesia and are grouped by province. The largest percentage of respondents' domicile in this study was in the province of West Java, which was 30.7 percent.

Evaluating the level of model fit can be done through several stages, namely the overall model fit, measurement model fit, and structural model fit (Hair et al., 2010). The respecification of the model can be done if the designed model is not in accordance with the built hypothesis (Wijayanto, 2008).

Testing the model's overall fit can be done by looking at the values of SRMR, RMSEA, GFI, AGFI, NFI, CFI, RFI, and PGFI. The value of the overall fit test of the model before and after the respecification can be seen in Table 1. The result of the overall fit test of the model shows that the final model can be accepted as a good fit.

Table 1 - Model's goodness of fit criteria

\begin{tabular}{|c|c|c|c|c|}
\hline \multicolumn{2}{|c|}{ GOF Measurements } & Cut Off & Result & Conclusion \\
\hline 1. & SRMR & $\leq 0.08$ & 0,057 & Good fit \\
\hline 2. & RMSEA & $\leq 0.08$ & 0,078 & Good fit \\
\hline 3. & GFI & $0<\mathrm{GFI}<1 ; \mathrm{GFI} \geq 0,9$ & 0,99 & Good fit \\
\hline 4. & AGFI & $0<\mathrm{AGFI}<1 ; \mathrm{AGFI} \geq 0,9$ & 0,98 & Good fit \\
\hline 5. & $\mathrm{NFI}$ & $0<\mathrm{NFI}<1 ; \mathrm{NFI} \geq 0,9$ & 0,98 & Good fit \\
\hline 6. & $\mathrm{CFI}$ & $0<\mathrm{CFI}<1 ; \mathrm{CFI} \geq 0,9$ & 0,99 & Good fit \\
\hline 7. & RFI & $0<\mathrm{RFI}<1 ; \mathrm{RFI} \geq 0,9$ & 0,96 & Good fit \\
\hline 8. & PGFI & $0<\mathrm{PGFI}<1$; higher value is better & 0,55 & Good fit \\
\hline
\end{tabular}


At this stage, the criteria for model fit are measured based on the significance of the indicator variables on the latent variables. The indicator is said to be significant if it has a loading factor of 0.5 and a t-value of 1.96 . Furthermore, to measure the measurement model, it is done by looking at the value of construct reliability and variance extracted from each construct in the model. The acceptable construct reliability value is 0.7 , while the acceptable variance extracted value is 0.5 . Based on the results of the study, perceived product quality, perceived value, consumer satisfaction, consumer trust, consumer ethnocentrism, and consumer loyalty have met the requirements of the loading factor $\geq 0.5, t$-value $\geq 1.96, C R \geq$ 0.7 , and of VE $\geq 0.5$ or the model is fit. The results of the complete measurement model test are presented in Table 2.

Table 2 - Loading factors, construct reliability, and variance extracted

\begin{tabular}{|c|c|c|c|}
\hline Latent Variable & Loading Factors & $\mathrm{CR}$ & VE \\
\hline Perceived Product Quality (PQ) & & 0,83 & 0,51 \\
\hline PQ1 This product is comfortable even when used for a long time & 0.77 & & \\
\hline PQ2 This product provides high color pigmentation in one swipe & 0.60 & & \\
\hline This product fulfills my need for a lipstick & 0.70 & & \\
\hline PQ4 This product is practical to use & 0.60 & & \\
\hline PQ7 $\quad$ This product gives me pleasure in every use & 0.85 & & \\
\hline Perceived Value (PV) & & 0,74 & 0,60 \\
\hline $\begin{array}{l}\text { PV1 Based on your experience buying local lipstick products, } \\
\text { which statement is true in your opinion? (Quality is lower than } \\
\text { the price; Quality according to price; Quality is higher than the } \\
\text { price) }\end{array}$ & 0.66 & & \\
\hline $\begin{array}{l}\text { Based on your experience buying local lipstick products, } \\
\text { those purchases are: } \\
\text { (Not the best buy; Equally good purchase; Best purchase) }\end{array}$ & 0.66 & & \\
\hline Consumer Satisfaction (S) & & 0,81 & 0,51 \\
\hline I am satisfied with the lasting power of this product & 0.67 & & \\
\hline I am satisfied with how comfortable this product is on the lips & 0.83 & & \\
\hline $\begin{array}{l}\text { I am satisfied because the color selection of the products } \\
\text { matches my preferences }\end{array}$ & 0.71 & & \\
\hline I feel satisfied because this product is easy to find & 0.64 & & \\
\hline Consumer Trust $(\mathrm{T})$ & & 0,90 & 0,69 \\
\hline This product never disappoints me & 0.85 & & \\
\hline $\begin{array}{l}\text { The quality I get is in line with the claims given by the } \\
\text { company }\end{array}$ & 0.79 & & \\
\hline The information provided by this product is reliable & 0.76 & & \\
\hline $\begin{array}{l}\text { I always feel comfortable even though I have applied the } \\
\text { product for a long time on the lips }\end{array}$ & 0.92 & & \\
\hline Consumer Ethnocentrism (E) & & 0,75 & 0,51 \\
\hline $\begin{array}{l}\text { With the same level of price and quality, I prefer local } \\
\text { products over foreign products }\end{array}$ & 0.96 & & \\
\hline $\begin{array}{l}\text { With the same price level, I prefer to buy local products even } \\
\text { though the quality is lower than foreign products }\end{array}$ & 0.58 & & \\
\hline $\begin{array}{l}\text { With the same quality, I prefer to buy local products even } \\
\text { though the price is higher }\end{array}$ & 0.54 & & \\
\hline Consumer Loyalty $(\mathrm{L})$ & & 0,92 & 0,74 \\
\hline $\begin{array}{l}\text { This brand has its uniqueness that I will repurchase in the } \\
\text { future }\end{array}$ & 0.88 & & \\
\hline $\begin{array}{l}\text { This brand meets my expectations, so I will always } \\
\text { repurchase this product }\end{array}$ & 0.96 & & \\
\hline I say positive things about this brand to others & 0.88 & & \\
\hline I am willing to pay more to get the benefits this brand provides & 0.69 & & \\
\hline
\end{tabular}

The structural model fit test was carried out after the overall model fit was analyzed. The approach used is to look at the t-value of each variable where the t-value must be greater than 1.96 to be declared accepted at a significance level of 0.05 (95\% confidence level). The results show that all hypotheses have a t-value of more than 1.96. Therefore, it can be concluded that all hypotheses are significant. 
Hypothesis testing in this study was carried out through path coefficient analysis and tvalue on the structural equation model. If the path coefficient value $>0.05$ and the t-count value $>1.96$, the influence between variables is significant. Meanwhile, the path coefficient value $<0.05$ and the $t$-value $<1.96$ are included in the insignificant category. The analysis indicates that perceived product quality positively affects perceived value $(0.43)$, and both perceived product quality and perceived value positively affect consumer satisfaction (respectively: 0.78 and 0.22 ). Further, consumer satisfaction (0.28), consumer trust $(0.28)$, and consumer ethnocentrism $(0.17)$ are affecting consumer loyalty. Thus, the results of data processing show that all proposed hypotheses are accepted $(\mathrm{H} 1-\mathrm{H} 7)$. The results of hypothesis testing are presented in Table 3.

Table 1 - Hypothesis test result

\begin{tabular}{|c|c|c|c|c|}
\hline \multicolumn{2}{|c|}{ Latent Variable } & Loading Factors & t-value & Conclusion \\
\hline Perceived Product Quality (PQ) & $\rightarrow$ Perceived Value $(P V)$ & 0.43 & $15.36^{*}$ & H1 accepted \\
\hline Perceived Product Quality (PQ) & $\rightarrow$ Consumer Satisfaction (S) & 0.78 & 21.91 & H2 accepted \\
\hline Perceived Value (PV) & $\rightarrow$ Consumer Satisfaction (S) & 0.22 & 3.46 & H3 accepted \\
\hline Consumer Satisfaction (S) & $\rightarrow$ Consumer Trust $(\mathrm{T})$ & 0.81 & 13.84 & H4 accepted \\
\hline Consumer Satisfaction (S) & $\rightarrow$ Consumer Loyalty (L) & 0.28 & $2.10^{*}$ & H5 accepted \\
\hline Consumer Trust $(\mathrm{T})$ & $\rightarrow$ Consumer Loyalty (L) & 0.28 & 2.66 & H6 accepted \\
\hline Consumer Ethnocentrism (E) & $\rightarrow$ Consumer Loyalty (L) & 0.17 & 5.49 & H7 accepted \\
\hline
\end{tabular}

In addition to the direct influence between variables, this study also found an indirect effect between variables. The indirect effect in this study is presented in Table 4. The results of data processing indicate that there is an indirect effect of perceived product quality on consumer satisfaction through perceived value $(0.10)$. In addition, there is also the influence of the perceived product quality on consumer loyalty through consumer satisfaction (0.45). Further, perceived value affects consumer loyalty through consumer satisfaction $(0.11)$. Consumer satisfaction affects consumer loyalty through consumer trust (0.23), perceived product quality affects consumer satisfaction through consumer trust $(0.71)$, and perceived value affects consumer satisfaction through consumer trust (0.18).

Table 2 - Indirect effect between variables

\begin{tabular}{|l|c|c|c|}
\hline \multicolumn{1}{|c|}{ Indirect Effect } & Loading Factor & t-value & Conclusion \\
\hline $\begin{array}{l}\text { Perceived Product Quality (PQ) } \rightarrow \text { Perceived Value (PV) } \\
\rightarrow \text { Consumer satisfaction (S) }\end{array}$ & 0,10 & $3,99^{*}$ & Significant \\
\hline $\begin{array}{l}\text { Perceived Product Quality (PQ) } \rightarrow \text { Consumer satisfaction } \\
(\mathrm{S}) \rightarrow \text { Consumer loyalty (L) }\end{array}$ & 0,45 & $8,39^{*}$ & Significant \\
\hline $\begin{array}{l}\text { Perceived Value (PV) } \rightarrow \text { Consumer satisfaction }(\mathrm{S}) \rightarrow \\
\text { Consumer loyalty }(\mathrm{L})\end{array}$ & 0,11 & $3,30^{*}$ & Significant \\
\hline $\begin{array}{l}\text { Consumer satisfaction }(\mathrm{S}) \rightarrow \text { Consumer trust }(\mathrm{T}) \rightarrow \\
\text { Consumer loyalty }(\mathrm{L})\end{array}$ & 0,23 & $2,68^{*}$ & Significant \\
\hline $\begin{array}{l}\text { Perceived Product Quality (PQ) } \rightarrow \text { Consumer satisfaction } \\
(\mathrm{S}) \rightarrow \text { Consumer trust }(\mathrm{T})\end{array}$ & 0,71 & $17,58^{*}$ & Significant \\
\hline $\begin{array}{l}\text { Perceived Value (PV) Consumer satisfaction }(\mathrm{S}) \rightarrow \\
\text { Consumer trust }(\mathrm{T})\end{array}$ & 0,18 & $3,52^{*}$ & Significant \\
\hline
\end{tabular}

\section{DISCUSSION OF RESULTS}

The analysis results show that the perceived product quality has a significant influence on perceived value. This indicates that the better the respondent's perception of the quality of local lipstick, the higher the respondent's perception of the product's value. In this study, respondents felt pleasured when using local lipstick products. The degree of pleasure is one aspect that is considered to describe the quality of a product (Solomon et al., 2011). The high pleasure makes consumers perceive that the product has good quality. On the other hand, if the respondent perceives a product as good quality, the respondent tends to consider the product valuable. 
Furthermore, the study results indicate that perceived product quality and perceived value significantly influence consumer satisfaction. This is following the research conducted by Gok et al. (2019), where there is a strong influence between perceived product quality and consumer satisfaction, as well as a study by Hellier et al. (2003) and Chiu and Cho (2019), which show that perceived value has a powerful influence on consumer satisfaction. In this study, most respondents agreed that the local lipstick they used fulfills their lipstick needs. Fulfillment of needs itself is one of the predictors of product quality (Solomon et al., 2011), which indicates that respondents consider the quality of local lipstick products to be good enough to meet the respondents' daily needs for a lipstick. In addition, in this study, respondents considered local lipstick they are often used to have a quality that matched the price. Respondents who pay low prices for high-quality goods will positively perceive the product's value. This value will develop and increase satisfaction, which will increase consumer intention to repurchase.

The results also show that the more satisfied respondents with the local lipstick, the greater their trust in the products. These results are supported by Ribbink et al. (2004), which state that consumer satisfaction is a driver for consumer trust. Furthermore, Morgan and Hunt (1994) show that a business must increase customer satisfaction and turn it into trust to get long-term relationships that benefit the company. These two variables are also proven to influence consumer loyalty of generation $z$ on local lipstick. The higher the respondent's satisfaction with the local lipstick product used, the higher the probability of respondent being loyal to the product. The results of this data processing are in accordance with research conducted by Puspaningrum (2018), which states there is a positive and significant relationship between customer satisfaction and loyalty.

The higher the respondents rely on a local lipstick, the higher their loyalty to the products they use. The trust factor is necessary for building a positive and close relationship between consumers and businesses (Balaji et al., 2016; Guenzi and Georges, 2010). These results are in accordance with Kassim et al. (2010) research, which states that ultimately consumer satisfaction and trust have a role in building consumer loyalty. Furthermore, the variable of consumer ethnocentrism is known to influence consumer loyalty of generation $z$. The higher the sense of ethnocentrism in the respondent, the higher the possibility that the respondent will remain loyal to the local lipstick they used. These results are supported by Abosag and Farah (2014) and Chaudhry et al. (2020), which states that consumers who have a high level of ethnocentrism tend to be more loyal to local products and have lower loyalty to foreign products.

Besides the direct effect between variables, there are indirect effects found between variables in this study, with consumer satisfaction and consumer trust as intervening variables. The three indirect effects with the most significant value found in this study are: (1) perceived product quality, consumer satisfaction, and consumer loyalty; (2) consumer satisfaction, consumer trust, and consumer loyalty; and (3) perceived product quality, consumer satisfaction, and consumer trust. The role of consumer satisfaction as a mediator between perceived product quality and consumer loyalty is in line with some previous literature (Zeithaml, 2000; Olsen, 2002; Darsono and Junaedi, 2006). Perceived product quality represents consumer perception toward a product's performance. Meanwhile, satisfaction reflects the impact of said product performance on consumers' feelings. It indicates that the better consumers perceive local lipstick quality, the more likely they are satisfied with the brand. A satisfied consumer is also most likely to be loyal. Kassim et al. (2014) explained that when the perceived quality of a product increases, customer satisfaction is also expected to improve, ultimately shaping brand loyalty.

In this study, consumer trust mediates the relationship between consumer satisfaction and consumer loyalty. This indicates that when a consumer is satisfied with the overall performance of local lipstick products, said consumer is more likely to have trust in the product. Then, the trust they develop towards the brand will turn into loyalty if the brand continues to maintain consumers' satisfaction with the product. This result aligns with Aurier and N'Goala (2010), which stated the importance of converting satisfaction into trust to keep the relationship between brands and consumers. The role of consumer trust as a mediator 
between consumer satisfaction and consumer loyalty is also stated in Garbarino and Johnson (1999) and Morgan and Hunt (1994), where trust is placed at the center of the relationship.

Furthermore, this study also found that perceived product quality indirectly affects consumer trust through consumer satisfaction. This result indicates that the better the quality of local lipstick products, the more likely the consumer is satisfied and promotes their trust in the said product. Trust plays a vital role in building consumer loyalty.

Managerial Implications. Based on the results of data processing and discussions carried out previously, several managerial implications can be formulated as alternative strategies that are beneficial for companies engaged in the beauty sector to retain Generation Z consumers. The research conducted in this study shows that consumer satisfaction and consumer trust have the most significant direct influence on the loyalty of Generation Z consumers to local lipstick products.

Based on path analysis, consumer satisfaction affects consumer loyalty. This shows that the higher consumer satisfaction with local lipstick products will increase consumer loyalty to these products. The most significant indicator that contributes to shaping consumer satisfaction is product convenience. This indicates that the convenience of local lipstick products when used influences consumer loyalty to these products. In addition, the aspect of color choice is also an aspect that contributes significantly to consumer satisfaction. This is also supported by research results showing that color is the central aspect that is considered the most important in selecting local lipstick products. Therefore, local lipstick businesses can improve product research and development to formulate local lipstick products that provide comfort when used and develop new color choices in line with Generation Z consumer preferences.

Furthermore, the aspect of consumer trust is proven to affect the increasing consumer loyalty of Generation Z. Therefore, it can be concluded that the increase in consumer confidence in local lipstick products will be accompanied by an increase in consumer loyalty to these products. The most significant indicator that contributes to shaping the variable of consumer confidence is the suitability of the quality received by the respondents. Therefore, to increase consumer loyalty, business actors need to ensure that the products that reach consumers are under the claims submitted by the company. One way to increase consumer confidence in product quality is to attach certificates related to product quality assurance on social media and product packaging. This is reinforced by the fact that Halal certification and BPOM are essential in selecting Generation Z consumers' local lipsticks.

Generation $Z$ itself is a digital native. They tend to use various social media accounts to interact with other people and as trusted sources of information. Therefore, one strategy that can be used is to promote social media marketing of local lipstick products, primarily through video content, by utilizing social media platforms such as Tiktok, Youtube, Instagram, and Twitter. In addition, companies can collaborate with beauty influencers in marketing their products. Another strategy that can be applied is to expand the marketing network for local lipstick products. Although more consumers purchase local lipstick products through ecommerce, companies still have to market offline products. One consumer ethnocentrism indicator supports this, stating that respondents bought foreign products because of the unavailability of local products in the market. With a broader product marketing network, more consumers have access to local lipstick products, which are expected to increase consumer loyalty in the future.

\section{CONCLUSION}

This study tries to reveal the relationship between several factors that can influence the loyalty of generation z consumers to local lipstick and then develop an appropriate loyalty model based on the study results. Based on the analysis results, it can be concluded that the factors studied influence consumer loyalty. The factors that build the loyalty model in this study are perceived product quality, perceived value, consumer satisfaction, consumer trust, and consumer ethnocentrism. Out of the various factors studied, consumer satisfaction and 
consumer trust are the two factors that have the most significant direct influence on consumer loyalty. Therefore, several forms of managerial implications that can be carried out are increasing product research and development to formulate local lipstick products that provide comfort, developing new color choices according to generation z's preference, showing the product quality assurance certificate, creating social media marketing, and expanding the marketing network of local lipstick products. Future research is expected to consider other variables influencing consumer loyalty, such as e-WOM, Key Opinion Leader, and Brand Image. Furthermore, the indicators used can be emphasized to describe the variables more specifically. For the local beauty industry, those who have and will produce local lipstick are expected to consider alternative strategies that can help increase consumer loyalty to local lipstick products.

\section{REFERENCES}

1. Abosag, I., \& Farah, M. (2014). The influence of religiously motivated consumer boycotts on brand image, loyalty, and product judgment. European Journal of Marketing, 48(11/12), 2262-2283. DOI: 10.1108/EJM-12-2013-0737.

2. Aurier, P., \& N'Goala, G. (2010). The differing and mediating roles of trust and relationship commitment in service relationship maintenance and development. Journal of the Academy of Marketing Science, 38(3), 303-325. DOI: 10.1007/S11747-009-0163-Z

3. Balaji, M. S., Roy, S. K., \& Wei, K. K. (2016). Does relationship communication matter in B2C service relationships?. Journal of Services Marketing, 30(2), 186-200. DOI: 10.1108/JSM-08-2014-0290.

4. [BPS]. Badan Pusat Statistik. (2021). Sensus Penduduk 2020. Available at: https://www.bps.go.id/website/materi_ind/materiBrsInd-20210121151046.pdf. [August 3rd 2021].

5. Chaudhuri, A., \& Holbrook, M. B. (2001). The chain of effects from brand trust and brand affect to brand performance: the role of brand loyalty. Journal of Marketing, 65(2), 81-93. DOI: 10.1509/JMKG.65.2.81.18255.

6. Chaudhry, N. I., Mughal, S. A., Chaudhry, J. L., \& Bhatti, U. T. (2020). Impact of consumer ethnocentrism and animosity on brand image and brand loyalty through product judgment. Journal of Islamic Marketing, 12(8), 1477-1491. DOI: 10.1108/JIMA03-2019-0057.

7. Chiu, W., \& Cho, H. (2019). E-commerce brand: The effect of perceived brand leadership on consumers' satisfaction and repurchase intention on e-commerce websites. Asia Pacific Journal of Marketing and Logistics, 33(6), 1339-1362. DOI: 10.1108/APJML-102018-0403.

8. Darsono, L. I., \& Junaedi, C. M. (2006). An examination of perceived quality, satisfaction, and loyalty relationship. Gadjah Mada International Journal of Business, 8(3), 323-342. DOI: 10.22146/GAMAIJB.5612.

9. Delafrooz, N., Paim, L. H., \& Khatibi, A. (2010). Students' online shopping behavior: An empirical study. Journal of American Science, 6(1), 137-147. DOI: 10.23883/IJRTER.2018.4418.UGWYZ.

10. Garbarino, E., Johnson, M. S. (1999). The different roles of satisfaction, trust, and commitment in customer relationships. Journal of Marketing, 63(2), 70-87. DOI: $10.2307 / 1251946$.

11. Gök, O., Ersoy, P., \& Börühan, G. (2019). The effect of user manual quality on customer satisfaction: the mediating effect of perceived product quality. Journal of Product \& Brand Management, 28(4), 475-488. DOI: 10.1108/JPBM-10-2018-2054.

12. Guenzi, P., \& Georges, L. (2010). Interpersonal trust in commercial relationships: Antecedents and consequences of customer trust in the salesperson. European Journal of Marketing, 44(1-2), 114-138. DOI: 10.1108/03090561011008637.

13. Hair, J. F., Black, W. C., Babin, B. J., Anderson, R. E., \& Tatham, R. L. (2010). SEM: An introduction. Multivariate data analysis: A global perspective. New Jersey (US): Pearson. 
14. Hellier, P. K., Geursen, G. M., Carr, R. A., \& Rickard, J. A. (2003). Customer Repurchase Intention. European Journal of Marketing, 37(11/12), 1762-1800. DOI: 10.1108/03090560310495456.

15. Jacobsen, S. L., \& Barnes, N. G. (2020). Social media, gen z and consumer misbehavior: instagram made me do it. Journal of Marketing Development \& Competitiveness, 14(3), 51-58. DOI: 10.33423/JMDC.V14I3.3062.

16. Kassim, N., \& Abdullah, N. A. (2010). The effect of perceived service quality dimensions on customer satisfaction, trust, and loyalty in e-commerce settings: A cross cultural analysis. Asia Pacific Journal of Marketing and Logistics, 22(3), 351-371. DOI: 10.1108/13555851011062269.

17. Kassim, A. W. M., Igau, O. A., Harun, A., \& Tahajuddin, S. (2014). Mediating effect of customer satisfaction on perceived product quality, perceived value, and their relation to brand loyalty. International Journal of Research in Management \& Business Studies, 1(2), 13-18. DOI: 10.1108/JPBM-10-2018-2054.

18. Kredivo \& Katadata Insight Center. (2020). Transaksi E-Commerce Didominasi Generasi $Z$ dan Milenial. Available at: https://www.alinea.id/gaya-hidup/transaksi-e-commercedidominasi-generasi-z-dan-milenial-b1ZRL9woj [November 11th 2020].

19. Morgan, R. M., \& Hunt, S. D. (1994). The commitment-trust theory of relationship marketing. Journal of Marketing, 58(3), 20-38. DOI: 10.2307/1252308.

20. Netzer, J. (2019). 5 Generation Z Statistics on Spending Habits That Marketers Need to Know. Available at: https://khoros.com/blog/5-stats-generation-z-buying-habits. [November 11th 2020].

21. Olsen, S. O. (2002). Comparative evaluation and the relationship between quality, satisfaction, and repurchase loyalty. Journal of The Academy of Marketing Science, 30(3), 240-249. DOI: 10.1108/MBE.2002.26706DAE.004.

22. Puspaningrum, A. (2018). Hypermarket customer loyalty: product attributes and image mediated by value and customer satisfaction. Journal of Business and Retail Management Research, 13(2), 84-97. DOI: 10.24052/JBRMR/V13IS02/ART-08.

23. Ribbink, D., Van Riel, A. C., Liljander, V., \& Streukens, S. (2004). Comfort your online customer: quality, trust and loyalty on the internet. Managing Service Quality: An International Journal, 14(6), 446-456. DOI: 10.1108/09604520410569784.

24. Schlossberg, M. (2016). Teen Generation Z is being called 'millennials on steroids,' and that could be terrifying for retailers. Available at: Business Insider UK http://uk.businessinsider.com/millennials-vs-gen-z-2016-2. [May 16th 2020].

25. Solomon, M. R., Marshall, G. W., \& Stuart, E. W. (2011). Marketing: Real People, Real Choices, Global Edition. Harlow (UK): Pearson Education Limited.

26. Wijayanto. (2008). Structural Equation Modeling dengan LISREL 8.8. Yogyakarta (ID): Graha IImu.

27. Zeithaml, V. A. (2000). Service quality, profitability, and the economic worth of customers: what we know and what we need to learn. Journal of the Academy of Marketing Science, 28(1), 67-85. DOI: 10.1177/0092070300281007. 